\title{
Is Africa a Net Creditor? \\ New Estimates of Capital Flight from Severely Indebted Sub-Saharan African Countries, 1970-1996
}

\author{
James K. Boyce and Léonce Ndikumana \\ Department of Economics and Political Economy Research Institute \\ University of Massachusetts \\ Amherst, MA 01003
}

\section{Corresponding author:}

Léonce Ndikumana

Department of Economics

Thompson Hall

University of Massachusetts

Amherst, MA 01003

Email: ndiku@econs.umass.edu

Tel: (413) 5456359

\section{Length of the text: 7,301 words}




\title{
Is Africa a Net Creditor? \\ New Estimates of Capital Flight from Severely Indebted Sub-Saharan African Countries, 1970-1996
}

\begin{abstract}
This paper presents estimates of capital flight from 25 low-income sub-Saharan African countries in the period 1970 to 1996. Capital flight totaled more than $\$ 193$ billion (in 1996 dollars); with imputed interest earnings, the accumulated stock of flight capital amounts to $\$ 285$ billion. The combined external debt of these countries stood at $\$ 178$ billion in 1996. Taking capital flight as a measure of private external assets, and calculating net external assets as private external assets minus public external debts, sub-Saharan Africa thus appears to be a net creditor vis-à-vis the rest of the world.
\end{abstract}




\section{Introduction}

The title of this paper will strike some as fanciful. Africa, a net creditor? Surely not. Or at least, surely not the low-income countries of sub-Saharan Africa, to whom the prefix 'heavily indebted' is routinely applied. For the past two decades, these countries have been forced by their crippling external debt burdens to undertake painful economic adjustments, while devoting scarce foreign exchange to debt-service payments. Of 38 countries worldwide classified by the World Bank as 'severely indebted low-income countries' (SILICs) in 1998, 29 were in sub-Saharan Africa.

There is a crucial difference, however, between countries and governments. Countries include private sectors as well as public sectors. Without exception, subSaharan African governments are indeed indebted, often severely so. But this does not necessarily mean that all the countries of the region are indebted, if a country is understood to comprise private citizens as well as their governments.

It is well-known, for example, that even as the governments they headed incurred large external debts, a number of individual African rulers amassed large personal fortunes, at least part of which were held abroad. Mobutu Sese Seko, who ruled Congo (or Zaire, as he renamed it) from 1965 to 1997, is reported to have accumulated \$4 billion in private assets by the mid-1980s (Burns et al., 1997). The Swiss bank accounts of the family of General Sani Abacha, who ruled Nigeria for five years, frozen in 1999 at the request of a new Nigerian government, reportedly contain as much as $\$ 2$ billion (Onishi, 
1999); a US Senate inquiry in the same year revealed that the Abacha family also held multi-million dollar accounts with Citibank in London and New York (Gerth, 1999; O’Brien, 1999).

The problem is that while public external debts are scrupulously recorded, many private external assets are scrupulously concealed. This makes it is difficult to compare them so as to arrive at a complete picture of a country's net external balance, taking into account the private sector as well as the public sector.

In this essay, we provide an estimate of this balance for the 'severely indebted' low-income countries of sub-Saharan Africa. To estimate private external assets, we use capital flight estimation techniques first developed in the mid-1980s by researchers at the World Bank and elsewhere (for an overview of these methods, see Lessard and Williamson, 1987). The starting point for our statistical detective work is the official Balance of Payments Statistics published annually by the International Monetary Fund (IMF), where discrepancies between recorded inflows and outflows of foreign exchange are reported as 'net errors and omissions.'

Capital flight researchers recognized that the official balance-of-payments (BoP) data conceal two further sources of errors. First, in the capital account, the recorded inflows of external borrowing are often considerably smaller than the corresponding amounts shown in the World Bank's World Debt Tables, implying that the BoP data on debt flows are incomplete. Second, in the current account the accuracy of the official 
BoP data on the value of exports and imports is undermined by widespread trade misinvoicing, motivated among other reasons by the desire to evade import restrictions or customs duties, and by the desire to evade controls on transferring foreign exchange out of the country. The extent of misinvoicing can be estimated by trading partner data comparisons, using data in the IMF's annual Direction of Trade Statistics.

After correcting the BoP data for underreported external borrowing and in some cases for trade misinvoicing, researchers recalculated net errors and omissions, thereby obtaining a 'residual' measure of capital flight (see, for example, World Bank, 1985; Erbe, 1985; Morgan Guaranty Trust Company, 1986; Lessard and Williamson, 1987). Summing annual capital flight over time, we can obtain a measure of private external assets, which can be compared to the host country's public external debts.

Following this methodology, we calculate capital flight for 25 sub-Saharan African countries for all the years from 1970 to 1996 for which the necessary data are available. Our 25-country sample consists of those countries classified by the World Bank as 'severely indebted low-income countries' for much of the past decade, for which adequate data are available. ${ }^{\text {G }}$ Our results indicate that in many of these countries including Angola, Cameroon, Congo-Zaïre, Côte d'Ivoire, Nigeria, and Zambia - private external assets accumulated via capital flight exceed the public external debt. In the region as a whole, whereas the total external debts of the 25 countries stood at $\$ 178$ billion in 1996, their cumulative capital flight amounted to $\$ 193$ billion in 1996 dollars, or to $\$ 285$ billion if the imputed interest earnings on flight capital are included in the 
total. Depending on which of these two measures of the stock of capital flight is used, it exceeded the stock of debt by $\$ 14.5$ billion to $\$ 106.5$ billion. Contrary to the common wisdom, the answer to the question in our title is 'Yes.'

The remainder of this paper is organized as follows. Section 2 reviews the existing literature on capital flight from sub-Saharan Africa, noting several limitations of previous estimates. Section 3 presents new estimates of African capital flight from 1970 to 1996 , incorporating adjustments for trade misinvoicing. We sum these estimates over time to obtain two alternative measures of the cumulative stock of capital flight: a conservative estimate adjusted only for inflation, and a more comprehensive estimate which includes imputed interest earnings. In Section 4, we compare these estimates to the external public debts of these countries. Finally, in Section 5 we offer some concluding remarks.

\section{Past Evidence on African Capital Flight}

Beginning in the mid-1980s, the phenomenon of capital flight from developing countries received considerable attention in the economics literature. A number of country-specific case studies and cross-country studies have examined the magnitude of capital flight, its causes, and its effects (see, among others, Morgan Guarantee Trust Co., 1986; Lessard and Williamson, 1987; Pastor, 1990; Boyce, 1992; Murinde, Hermes, and Lensink, 1996; Ajayi, 1997). Until recently, however, sub-Saharan Africa has received less attention than other developing regions. 
Yet capital outflows from African economies deserve serious attention for several reasons. First, capital flight constitutes a diversion of scarce resources away from domestic investment and other productive activities. In recent decades, African economies have achieved significantly lower investment levels than other developing countries (International Financial Corporation, 1998; Ndikumana, 2000). These low levels of domestic investment are attributable, in part, to the apparent scarcity of domestic savings, weak and shallow financial systems, and high country risk due to unstable macroeconomic and political conditions. Capital flight is both a cause and a symptom of this weak investment performance.

Second, capital flight is likely to have pronounced regressive effects on the distribution of wealth. The individuals who engage in capital flight generally are members of the subcontinent's economic and political élites, who take advantage of their privileged positions to acquire and channel funds abroad. Both the acquisition and the transfer of funds often involve legally questionable practices, including the falsification of trade documents (trade misinvoicing), the embezzlement of export revenues, and kickbacks on public and private sector contracts (see, for example, Ndikumana and Boyce, 1998). The negative effects of the resulting shortages of revenue and foreign exchange fall disproportionately on the shoulders of the less wealthy members of the society. The regressive impact of capital flight is compounded when financial imbalances result in devaluation: the wealthy who hold external assets are insulated from its effects, while the poor enjoy no such cushion. 
A third reason for greater attention to African capital flight is that most subSaharan African countries remain in the grip of a severe external debt crisis. Debt service today absorbs a sum equivalent to more than $6 \%$ of sub-Saharan's GDP. ${ }^{\text {Insofar as the }}$ proceeds of external borrowing were used not to the benefit of the African public, but rather to finance the accumulation of private external assets by the ruling élites, the moral and legal legitimacy of these debt-service obligations is open to challenge.

\section{Quantitative studies}

Past studies have revealed significant capital outflows from sub-Saharan African countries since the 1970s. The estimated magnitudes of capital flight have varied, primarily due to differences in data and time-period coverage. The standard methodology is to calculate capital flight as the residual difference between capital inflows and recorded foreign-exchange outflows. Capital inflows consist of net external borrowing plus net foreign direct investment. Recorded foreign-exchange outflows comprise the current account deficit and net additions to reserves and related items. The difference between the two constitutes the measure of capital flight. If the sole source of data for this calculation were the official balance-of-payments statistics, this would be equivalent to the 'net errors and omissions' reported therein. In practice, more accurate estimates of the change in external debt outstanding can be obtained from other sources, such as the World Bank's World Debt Tables. Using this approach, which was introduced in pioneering studies by the World Bank (1985) and Erbe (1985), capital flight $(K F)$ in a given year $t$ for a country $i$ is thus computed as: 


$$
K F_{i t}=\Delta D E B T_{i t}+D F I_{i t}-\left(C A_{i t}+\Delta R E S_{i t}\right)
$$

where $\triangle D E B T$ is the change in total external debt outstanding, DFI is net direct foreign investment, $C A$ is the current account deficit, and $\triangle R E S$ is net additions to the stock of foreign reserves. $^{0}$

In an early cross-country study on capital flight from sub-Saharan Africa, prepared for a World Bank volume on African external finance, Chang and Cumby (1991) examined a sample of 36 African countries from 1976 to 1987 . They found that with the exception of Nigeria, the absolute levels of capital flight from individual African countries were smaller than those from Latin American countries, but that relative to external debt and GDP, many African countries experienced higher capital flight than their Latin American counterparts.

Hermes and Lensink (1992) estimated capital flight from six countries (CongoZaïre, Côte d'Ivoire, Nigeria, Sudan, Tanzania, and Uganda) over the period 1976 to 1989. They used the somewhat narrower 'non-bank' definition proposed by Morgan Guaranty Trust (1986), which excludes assets held abroad by domestic banks from the definition of capital flight. ${ }^{6}$ Their estimates again indicate that while total capital flight from sub-Saharan African countries may seem small compared to that from Latin American countries, the burden of capital flight (as a percent of GDP) is higher: $61 \%$ for the sub-Saharan sample compared to $22 \%$ for Latin America (also see Murinde, Hermes, and Lensink, 1996). By their calculations, Nigeria experienced the largest capital fight 
over the period, $\$ 21$ billion, representing $60 \%$ of the combined total for the six countries in the sample. Their econometric analysis of the determinants of capital flight indicates that the most important explanatory variable is public external borrowing: of each dollar of public or publicly-guaranteed long-term borrowing, 75 to 90 cents appears to be 'reexported as capital flight' (Hermes and Lensink, 1992: 526). These results are consistent with the hypothesis that capital flight and external debt are closely intertwined (Boyce, 1992, 1993).

Ojo (1992) estimated capital flight from three heavily indebted countries - Côte d'Ivoire, Morocco, and Nigeria - from 1975 to 1991 . Cumulative capital flight from the two sub-Saharan countries, Côte d'Ivoire and Nigeria, was found to be very large, at $\$ 10.9$ billion and $\$ 35.9$ billion, respectively. The author's analysis of the determinants of capital flight from these countries emphasized the importance of the domestic economic environment, including such policy-related variables as the government budget deficit and changes in external reserves.

Nyatepe-Coo (1994) estimated capital flight from seven sub-Saharan African countries (Congo-Zaïre, Ghana, Kenya, Nigeria, Sierra Leone, Tanzania, and Zambia) in the period 1970 to 1992 . The study finds heavy capital outflows from Nigeria, Ghana, Congo-Zaïre, and Zambia: relative to external borrowing, capital flight was equivalent to $91 \%, 58 \%, 35 \%$, and $32 \%$, respectively. For Kenya and Tanzania, by contrast, the corresponding ratios were only $9 \%$ and $2 \%$, respectively, and for Sierra Leone, estimated capital flight was negative (implying unrecorded capital inflows). The study associates 
capital flight with political instability, macroeconomic uncertainty, and weak credibility of government policies.

In a study of capital flight from severely indebted low-income countries in subSaharan Africa over the period 1980 to 1991, Ajayi (1997) finds that cumulative capital flight in the period averaged $40 \%$ of external debt for an 18-country sample, and that the ratio was as high as $94 \%$ for Nigeria and Rwanda, $74 \%$ for Kenya, and $60 \%$ for Sudan (Ajayi, 1997: 17). Observing that the countries that exhibit the greatest capital flight often are also the most highly indebted, Ajayi characterizes these as "twin problems". He uses trading-partner data comparisons to estimate the net effect of trade misinvoicing, which can be added to capital flight as measured in equation (1) to yield an adjusted measure. This results in both upward and downward adjustments of capital flight estimates, depending on whether export underinvoicing and import overinvoicing (both of which are common mechanisms of capital flight) outweigh import underinvoicing (that is, pure or technical smuggling to evade customs duties and restrictions) in the country in question.

In addition to these cross-country studies, several studies have focused on capital flight from individual African countries. Smit and Mocke (1991) estimated that capital flight from South Africa over the period 1970 to 1988 amounted to between $\$ 12$ billion and $\$ 23$ billion, depending on the measure used. They point out that these amounts are large on international standards, and that during the late 1970s capital flight from South Africa exceeded that from Argentina, Brazil, or the Philippines (Smit and Mocke 1991: 
107). Ajayi (1992) estimated capital flight from Nigeria in 1972-1989, drawing

particular attention to the role of 'trade faking' (that is, misinvoicing) in the country's oil sector and to the links between capital flight, corruption, and governance failures. Ndikumana and Boyce (1998) find that from 1968 to 1990, the real stock of capital flight from Zaïre amounted to roughly $\$ 12$ billion (in 1990 dollars), and suggest that capital flight was fueled by lax lending practices by foreign banks and multilateral financial institutions, as well as by irresponsible debt management and the embezzlement of export revenues under the Mobutu regime.

\section{Limitations of past estimates}

The past estimates of capital flight from Sub-Saharan Africa have several important limitations. First, with a few exceptions (Chang and Cumby, 1991; Ajayi, 1997), they cover a small number of countries. Therefore, they do not offer a basis for extensive cross-country analyses of the magnitude, causes, and consequences of capital flight. Moreover, those studies which do cover a large sample of countries only refer to a fairly short time period, which limits our ability to examine the trends in capital flight over time. For time-series analysis, it would be useful to have estimates of capital flight both in the pre-debt crisis years of heavy external borrowing and since the onset of the crisis in the 1980s.

Second, in deriving residual measures of capital flight, past studies have not taken into account the effect of exchange rate fluctuations on the U.S. dollar value of end-of- 
year debt stocks. Depending on whether these currencies depreciate or appreciate against the dollar, this can introduce a downward or upward bias in measured capital flight. This problem is especially relevant in countries where a substantial portion of the debt is denominated in other currencies, as in the Francophone countries of sub-Saharan Africa, where much debt is denominated in the French franc.

Third, again with a few exceptions (Chang and Cumby, 1991; Ajayi, 1992, 1997; Ndikumana and Boyce, 1998), most past estimates pay no attention to the falsification of trade transactions. Instead they take the trade statistics (unlike the capital account statistics) in the official Balance of Payments tables at the face value. In practice, the official BoP data on exports and imports are often of poor quality due to trade misinvoicing. Exporters may understate the value of their export revenues, so as to retain abroad the difference between their true value and their declared value. On the import side, there are incentives for both overinvoicing and underinvoicing: overinvoicing allows importers to obtain extra foreign exchange, which can then be transferred abroad, from the central bank at favorable terms; underinvoicing and outright smuggling allow

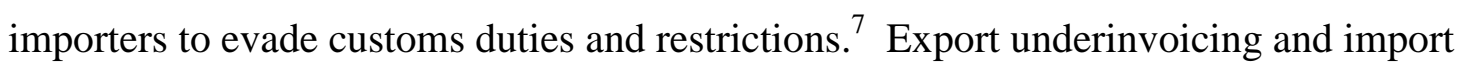
overinvoicing both inflate the current account deficit recorded in the balance of payments; import underinvoicing leads to understatement of the true deficit. If the true current account deficit is overstated, the capital flight estimate obtained using balance-ofpayments trade data (equation 1) will be too low: further capital flight is hidden in trade accounts. If the true current account deficit is understated, the capital flight estimate will be too high: some of the missing foreign exchange was in fact used to finance unrecorded imports. The net effect of trade misinvoicing can only be ascertained 
empirically. ${ }^{\mathrm{B}}$ The studies which have considered this issue flight have found that trade misinvoicing is a significant net addition to total capital flight in some countries in some years (see, for example, Ajayi 1997, and Ndikumana and Boyce 1998).

Finally, with the exception of the study of Congo-Zaïre by Ndikumana and Boyce (1998), none of cumulative estimates of African capital flight reported in past studies have taken into account the fact that a dollar which fled in, say, 1976 does not have the same value as a dollar which fled 10 or 20 years later. In principle, dollars which fled at different dates can be made comparable either by adjusting for inflation (that is, converting nominal dollars into real terms expressed in some constant base-year value) or by imputing interest earnings on capital flight which left in earlier years. $\square_{\text {As long as the }}$ real interest rate is positive, the cumulative stock of flight capital will be higher when calculated by the latter method than by the former. Which method of adjustment of the nominal estimates is preferable depends on the intended uses of the data. If the aim is to examine trends, or to analyze econometrically the causes or consequences of capital flight, then the inflation-adjusted real estimates are appropriate. If the aim is to assess the opportunity cost of capital flight, or to compare cumulative capital flight to the stock of external debt (which, of course, includes capitalized interest arrears and borrowing to cover the interest payments), then interest-adjusted estimates are more germane.

\section{New Estimates of African Capital Flight}

In this section, we present the most comprehensive set of estimates of capital flight from the "severely indebted low-income countries" (SILICs) of sub-Saharan Africa 
reported to date. Our data refer to 25 countries, covering whenever possible the 27 -year period from 1970 to 1996. The estimates incorporate adjustments for trade misinvoicing and exchange rate fluctuations, the details of which are explained below. Two sets of estimates of cumulative capital flight are presented, one using an inflation adjustment, the other using imputed interest earnings.

\section{Sample}

Our sample includes 25 sub-Saharan countries classified as SILICs by the World Bank: Angola, Burkina Faso, Burundi, Cameroon, Central African Republic, the Democratic Republic of Congo (the former Zaïre), the Republic of Congo, Côte d'Ivoire, Ethiopia, Ghana, Guinea, Kenya, 10 Madagascar, Malawi, Mali, Mauritania, Mozambique, Niger, Nigeria, Rwanda, Sierra Leone, Somalia, Sudan, Tanzania, Uganda, and Zambia. The sample excludes SILICs for which consistent data are not available (Equatorial Guinea, Guinea-Bissau, Liberia, Saõ Tomé and Principe, and Somalia). The sample also excludes sub-Saharan African countries classified as low-income but not as severely indebted (Benin, Chad, Comoros, Eritrea, Gambia, Lesotho, Senegal, Togo, and Zimbabwe), and those not classified as low-income countries (Botswana, Cape Verde, Djibouti, Gabon, Mauritius, Mayotte, Namibia, Seychelles, South Africa, and Swaziland). The countries in our sample account for $86 \%$ of the population, $80 \%$ of the debt, and $43 \%$ of the GDP of all sub-Saharan African countries, and for $92 \%$ of the population, $91 \%$ of the debt, and $93 \%$ of the subcontinent's GDP excluding South Africa. 11 


\section{Methodology}

We define capital flight as the difference between total capital inflows and recorded foreign exchange outflows. We calculate capital flight using equation (1) above, with three important modifications. $\frac{12}{2}$ First, we take into account the impact of exchange rate fluctuations on the U.S. dollar value of the stock of long-term debt. Second, we take into account trade misinvoicing by means of trading partner data comparisons, using the IMF's Direction of Trade Statistics Yearbook for this purpose. We thereby obtain nominal capital flight estimates adjusted for trade misinvoicing. Third, we compute estimates of adjusted capital flight that either correct for inflation (using the US producer price index) or incorporate accumulated interest earnings on past capital flight (using the US Treasury Bill rate).

\section{Adjustment for exchange rate fluctuations}

The World Bank's debt data are reported in a common currency, the U.S. dollar. Yet countries hold debts denominated in a variety of currencies (see Table 1). In the World Bank data on debt stocks, these are converted to dollars using the end-of-year exchange rate. In periods of significant fluctuations in the exchange rates of the currencies in which the debt is denominated, year-to-year changes in the dollar value of the stock of outstanding debt can differ markedly from the actual net flows during the year. If so, estimates of capital flight based on equation (1) will be biased. For a country that held French franc-denominated debt, for example, the depreciation of the French franc from $4.0 \mathrm{FF} / \$$ at the end of 1979 to $9.6 \mathrm{FF} / \$$ at the end of 1984 reduced the dollar valuation of this portion of its debt stock. Estimates of capital flight derived from the 
apparent change in the debt stock would be correspondingly reduced. Conversely, when other currencies in which debt is denominated appreciate against the dollar, estimates of capital flight are inflated.

To correct for these potential discrepancies, we adjust the change in the long-term debt stock for fluctuations in the exchange rate of the dollar against other currencies. Total debt stock is the sum of long-term debt, short-term debt, and the use of IMF credit. IMF credit is denominated in Special Drawing Rights (SDR), while long-term debt and short-term debt are denominated in various currencies. The World Bank's Global Development Finance reports annual data on long-term debt composition for seven major currencies: the French franc, the German Deutsche mark, the Japanese yen, the Swiss franc, the SDR, the UK pound, and the US dollar (see Table 1).

\section{[INSERT TABLE 1 HERE]}

Using these data, we calculate the change in the U.S. dollar value of the debt stock carried over from the previous year that is attributable to exchange-rate movements in the current year. We do so by revaluing the beginning-of-year debt stock using end-ofyear exchange rates, and calculating an 'exchange-rate adjustment' equal to the difference between this number and the beginning-of-year debt stock valued at beginning-of-year exchange rates. This difference is subtracted from $\triangle D E B T$ to get an adjusted measure, $\triangle D E B T A D J$, that captures the change in the debt stock attributable to net borrowing in the period. In other words, $\triangle D E B T A D J$ is the difference between the 
end-of-year debt stock and the beginning-of-year debt stock, when both are valued at end-of-year exchange rates. The portion of long-term debt held in multiple currencies and unspecified currencies is left unadjusted, as is the short-term debt. 3

For country $i$, the U.S. dollar value of the beginning-of-year stock of debt at the new exchange rates is obtained as follows:

$$
\begin{aligned}
& \operatorname{NEWDEBT}_{i, t-1}=\sum_{j=1}^{6}\left(\alpha_{i j, t-1} * \operatorname{LTDEBT}_{i, t-1}\right) /\left(E X_{j t} / E X_{j, t-1}\right)+ \\
& \operatorname{IMFCR}_{i, t-1} /\left(\mathrm{EX}_{S D R, t} / \mathrm{EX}_{S D R, t-1}\right)+\operatorname{LTOTHER}_{i, t-1}+\operatorname{LTMULT}_{i, t-1}+ \\
& \operatorname{LTUSD}_{i, t-1}+\operatorname{STDEBT}_{i, t-1}
\end{aligned}
$$

where $L T D E B T$ is the total long-term debt; $\alpha_{i j}$ is the proportion of long-term debt held in currency $j$, for each of the six non-US currencies; $E X$ is the end-of-year exchange rate of the currency of denomination against the dollar (expressed as units of currency per U.S. dollar); IMFCR is the use of IMF credit; LTOTHER is long-term debt denominated in other unspecified currencies; LTMULT is long-term debt denominated in multiple currencies; LTUSD is long-term debt denominated in U.S. dollars; and STDEBT is shortterm debt.

The exchange rate adjustment is obtained as:

$$
E R A D J_{t}=N E W D E B T_{t-1}-D E B T_{t-1}
$$

We then obtain the adjusted change in debt as:

$$
\triangle D E B T A D J_{t}=\triangle D E B T_{t}-E R A D J_{t}
$$


Since $\triangle D E B T_{t}=D E B T_{t}-D E B T_{t-1}$, it follows that (4) is equivalent to:

$$
\triangle D E B T A D J_{t}=D E B T_{t}-N E W D E B T_{t-1}
$$

We modify equation (1) to get a residual measure of capital flight adjusted for exchange rate fluctuations:

$$
K F_{i t}=\triangle D E B T A D J_{i t}+D F I_{i t}-\left(C A_{i t}+\Delta R E S_{i t}\right)
$$

\section{Adjustment for trade misinvoicing}

We estimate trade misinvoicing by comparing the country's export and import data to those of its trading partners. These are reported in the IMF's annual publication Direction of Trade Statistics Yearbook. We assume that the trade data from industrialized countries are relatively accurate, and interpret the discrepancy between these and the data from their African trading partners as evidence of misinvoicing.

For an individual African country $i$ in year $t$, export discrepancies with the industrialized countries $(D X I C)$ are computed as follows:

$$
D X I C_{i t}=P X I C_{i t}-\left(X I C_{i t} * C I F_{t}\right)
$$

where $P X I C$ is the value of the industrialized countries' imports from the African country as reported by the industrialized trading partners, $X I C$ is the African country's exports to industrialized countries as reported by the African country, and CIF is the c.i.f/f.o.b factor, representing the costs of freight and insurance. ${ }^{4}$ A positive sign on DXIC indicates export underinvoicing. 1.5 
Import discrepancies with the industrialized countries (DMIC) are computed as:

$$
D M I C_{i t}=M I C_{i t}-\left(P M I C_{i t} * C I F_{t}\right)
$$

where $M I C$ is the African country's imports from industrialized countries as reported by the African country, and PMIC is the industrialized countries' exports to the African country as reported by the industrialized trading partners. A positive sign on DMIC indicates net overinvoicing of imports; a negative sign indicates net underinvoicing.

To obtain global totals, we multiply these discrepancies by the inverse of the average shares of industrialized countries in the African country's exports $(I C X S)$ and

imports ICMS. $\frac{16}{6}$ We obtain total trade misinvoicing as the sum of export discrepancies and import discrepancies:

$$
\operatorname{MISINV}_{i t}=\frac{D X I C_{i t}}{I C X S_{i}}+\frac{D M I C_{i t}}{I C M S_{i}}
$$

Adding trade misinvoicing to the initial estimate of capital flight from equation (5) we obtain adjusted capital flight as:

$$
A D J K F_{i t}=K F_{i t}+M I S I N V_{i t}
$$

\section{Inflation adjustment}

To make annual capital flight estimates comparable over an extended period of time, we convert nominal flows to constant dollars, using the US producer price index for this purpose. The resulting data allow us to examine year-to-year changes in the real magnitude of capital flight and to compare the values of capital flight to other aggregates, 
such as the stock of debt or real gross domestic product. Real capital flight (adjusted for trade misinvoicing) is calculated as:

$$
R A D J K F_{i t}=A D J K F_{i t} / P P I_{t}
$$

where PPI is the US producer price index (base 1996=1.00).

\section{Adjustment for interest earnings}

Some of the capital that fled African countries was used to finance the acquisition of assets abroad, including fixed assets such as real estate, and liquid and semi-liquid assets such as savings deposits and stocks. These assets gain value over time through market appreciation or interest earnings: a dollar invested abroad in 1970 is worth more than a dollar today due to these accumulated earnings. No doubt some of the funds which fled African countries were used to finance consumption, rather than being invested, but there is no easy way to estimate the proportions of capital flight which were consumed and saved. Imputing interest earnings to the entire amount of capital flight provides an estimate of its opportunity cost to the nation, on the assumption that this capital would have otherwise been available for investment. We compute the stock of interest-earnings adjusted capital flight $(S A D J K F)$ as follows:

$$
S A D J K F_{i t}=S A D J K F_{i, t-1}\left(1+T B I L L_{i t}\right)+A D J K F_{i t}
$$

where TBILL is the interest rate on short-term US Treasury bills. 7

\section{Results}


Table 2 presents our initial capital flight estimates in real US dollars (1996 prices) with adjustments for exchange rate fluctuations before adjustments for trade misinvoicing. Since the number of observations is not identical for all countries, due to missing data for certain years, cross-country comparisons are best made on the basis of the average annual capital flight as opposed to cumulative totals. For the sample as a whole, total capital flight by this measure amounted to $\$ 152$ billion. The results show wide cross-country variations in the magnitude of capital flight. Nigeria leads with a remarkable $\$ 63$ billion in capital flight over the 27 -year period, or roughly $\$ 2.3$ billion per annum. Angola, Côte d'Ivoire, and Sudan follow with roughly \$1.5 billion, \$616 million, and $\$ 513$ million per year, respectively. These results are broadly comparable to the findings of other authors who have investigated capital flight for specific countries and time periods using the same or similar methodology. 8

\section{[INSERT TABLE 2 HERE]}

Table 3 presents summary data on trade misinvoicing, again in real (1996) dollars. For most countries in the sample, we find evidence of substantial export underinvoicing: exporters appear to understate the true value of their earnings so as to retain funds abroad, a well-known mechanism of capital flight. Nigeria, with more than $\$ 16$ billion in export underinvoicing, again leads the way, followed closely by Congo-Zaïre. On the import side, there are some cases of net overinvoicing - Nigeria again being the most striking example - but in most cases imports appear to be, on the whole, underinvoiced: in other words, smuggling outweighs import overinvoicing. Combining export and import 
misinvoicing, we get a mixed picture: for fifteen countries, the sign of the misinvoicing adjustment is positive, meaning net additions to our initial estimates of capital flight; for ten it is negative, meaning net subtractions. For the region as a whole, however, the net effect is to add $\$ 40.6$ billion to our total estimate of capital flight.

\section{[INSERT TABLE 3 HERE]}

Our final estimates of capital flight, adjusted for trade misinvoicing, are presented in Table 4. The first column shows total capital flight in real 1996 US dollars; the second column shows accumulated capital flight, including imputed interest earnings. For the

25-country sample as a whole, real capital flight totaled $\$ 193$ billion, led by Nigeria with $\$ 86.8$ billion, or nearly $45 \%$ of the total. With imputed interest earnings the accumulated stock of capital fight is even larger, since real interest rates were positive in much of the period: the stock amounts to $\$ 285$ billion for the sample as a whole, including $\$ 129.6$ billion for Nigeria, \$34.7 billion for Côte d'Ivoire, and \$22.9 billion for Congo-Zaïre. These results suggest that the opportunity cost of capital flight has been high indeed for sub-Saharan African countries.

[INSERT TABLE 4 HERE]

Annual data on real capital flight, adjusted for trade misinvoicing, are reported in Table A1 in the appendix. These data will be useful in future analyses of the causes and 
consequences of capital flight from sub-Saharan Africa. The data indicate that capital flight was not solely a phenomenon of the onset of the debt crisis of the 1980s. For most countries, the amounts of capital flight in the 1970s were non-negligible; indeed, the outflows of the 1970s were often comparable to, and in some cases greater than, those of the 1980s. Over the period, a number of countries appear to have experienced episodes of capital flight reversal (that is, net outflows followed by net inflows), but outflows more than outweigh inflows for all but two countries (Mali and Niger) in the period as a whole.

To permit more meaningful cross-country comparisons of the magnitude of capital flight, given the variations in the sizes of their economies, Table 5 presents indicators of capital flight relative to income and population. The first column shows the average ratio of annual capital flight to GDP for each country. By this measure, Angola, Mozambique, and Zambia stand out as having experienced the most serious capital flight, equivalent to roughly $19 \%$ of GDP for Angola, and 12\% of GDP for Mozambique and Zambia. ${ }^{20}$ Nigeria and Côte d'Ivoire follow with average capital flight at $8.4 \%$ and $7.9 \%$ of GDP, respectively. For the sample as a whole, annual capital flight was equivalent, on average, to $3.8 \%$ of GDP. The second column reports the ratio of accumulated capital flight, with imputed interest earnings, to 1996 GDP. By this measure, Congo-Zaïre, Côte d'Ivoire, Nigeria, and Zambia experienced the greatest capital flight, the accumulated stock of which was more than four times their national incomes. In four countries, capital flight per capita is more than twice as large as per capita GDP. 1 The third column shows that on a per capita basis, the total stock of capital flight with imputed 
interest earnings is highest for Côte d'Ivoire, at more than \$2,500, followed by Angola, Cameroon, Nigeria, and Zambia, each of which exceeds $\$ 1,000$ per capita. For the sample as a whole, the cumulative stock of capital flight per capita is roughly $\$ 583$, more than double the region's per capita income in 1996.

\section{[INSERT TABLE 5 HERE]}

\section{Balancing the Books: External Assets and Liabilities}

In this section, we compare the private external assets of the 25 sub-Saharan African countries, as measured by their cumulative stock of capital flight, to their public external liabilities. Where the former exceed the latter, the countries (as opposed to their governments) can be regarded as net creditors vis-à-vis the rest of the world.

To be sure, not all of the capital which fled sub-Saharan Africa between 1970 and 1996 was saved and invested at normal rates of return. Some of the flight capital was spent on consumption, and some of the savings may have earned sub-normal rates of

return. 22 Hence there may be a gap between our measure of private external assets - that is, cumulative capital flight - and the external assets which remain in the hands of private Africans today. Nevertheless, the stock of capital flight provides a suitable basis for comparisons with sub-Saharan Africa's external liabilities, as well as a measure of capital flight's opportunity cost to the source countries. In terms of uses of funds, public external debts likewise include monies channeled to consumption and invested at subnormal rates of return. In terms of claims, it is not evident that the fraction of their 
'assets' which sub-Saharan Africa's external creditors can expect to recover is any higher

than the fraction of capital flight which private Africans can now claim. 3 In this section, we take both external assets and external liabilities at their 'face value'.

Table 6 presents data on the external debts and net external assets of the 25 subSaharan African countries in our sample. 'Net external assets' are here defined as cumulative capital flight minus external debt. When net external assets are positive, the country is a net creditor; when negative, the country is a net debtor. We report two alternative measures of net external assets, corresponding to the two measures of cumulative capital flight derived in section 3 . The first measure is more conservative, as it is based on the accumulated stock of capital flight in constant 1996 dollars, without imputed interest earnings. In effect, this measure values capital flight from earlier years with a real interest rate of zero. The second and more comprehensive measure, based on the stock of capital flight with interest, is arguably more appropriate for comparison with the stock of external debt, since the latter includes accumulated interest arrears and borrowing to finance interest on past loans. Both measures of net external assets are conservative, however, in one important respect: our estimates of capital flight cover only the years 1970 to 1996 (and in some cases, a shorter period), whereas the debt stock includes the pre-1970 balance and all subsequent additions to it.

[INSERT TABLE 6 HERE] 
By both measures, we find that the 25 'severely indebted countries' taken as a group are net creditors. Even without interest earnings, real capital flight exceeded external debt by almost $\$ 14.5$ billion. Including the imputed interest earnings on flight capital, the net external assets of the 25 countries totaled $\$ 106.5$ billion. These amounts are equivalent to $10 \%$ and 76\%, respectively, of these countries' combined GDP in 1996.

Among the individual countries, nine have positive net external assets. With more than $\$ 98$ billion by the more comprehensive measure, Nigeria's net external assets amount to $\$ 858$ per capita, nearly three times the country’s per capita income. Net external assets by this measure are 1.7 times national income for Congo-Zaïre and Rwanda, and 1.4 times for Côte d'Ivoire and Zambia.

A noteworthy feature of these results is that the countries with the largest external debts appear, in general, to have experienced the most capital flight, when both variables are measured relative to national income (see Figure 1). Simple regressions indicate that the debt-to-GDP ratio 'explains' $19 \%$ of the inter-country variations in the capital flightto-GDP ratio. When we examine the timing of debt inflows and capital flight outflows, the two variables again appear to be related. For the 25-country sample as a whole, the Pearson correlation coefficient between annual debt inflows and capital flight (both in 1996 dollars) is 0.54; using three-year moving averages for both variables, the correlation is 0.18 (see Figure 2). 


\section{[INSERT FIGURE 1 HERE]}

\section{[INSERT FIGURE 2 HERE]}

These cross-sectional and time-series relationships suggest the presence of linkages between external borrowing and capital flight. These could include causal connections in either direction - from borrowing to capital flight and vice versa - and/or links attributable to exogenous variables, such as macroeconomic mismanagement, which drove both borrowing and capital flight. ${ }^{24}$ Analysis of these linkages is a potentially fruitful area for further research.

\section{Conclusion: Who Should Forgive Whom?}

The evidence presented in this essay leads to a startling conclusion: far from being heavily indebted, many sub-Saharan African countries are net creditors vis-à-vis the rest of the world. This is because their private external assets, as measured by cumulative capital flight, are greater than their public external debts. For the 25-country sample as a whole, external assets exceed external debts by $\$ 14.5$ billion to $\$ 106.5$ billion, depending on whether we count imputed interest earnings on the asset side. The region's assets are 1.1 to 1.6 times the stock of debts. For some individual countries, the results are even more dramatic: Nigeria's external assets are 2.8 times its external debt by the conservative measure, and 4.1 times higher when we include imputed interest earnings on capital flight. 
At a minimum, these findings suggest a need for greater precision in discussions of sub-Saharan Africa's external debt burden: instead of 'severely indebted low-income countries,' or SILICs, we could more accurately speak of 'severely indebted low-income governments,' or SILIGs. In analyzing the economic plight of sub-Saharan African countries and their people, as distinct from that of their governments, we should not focus exclusively on public external liabilities, but also consider the private external assets built through capital flight. Both sides of the coin are deeply implicated in the region's current economic travails.

If sub-Saharan Africa is truly a net creditor, why are so many of its people so poor? The answer, of course, is that the subcontinent's private external assets belong to a narrow, relatively wealthy stratum of its population, while public external debts are borne by the populace at large through their governments. This asymmetry is not only regrettable, in that it exacerbates poverty in a region in which many are already desperately poor. It also raises profound questions as to precisely what belongs to whom, that is, how rights to external assets and responsibilities for external liabilities are to be distributed across the population.

Rights to sub-Saharan Africa's 'private' external assets are by no means clearly defined or incontestable. The fact that the Nigerian government has been able to obtain a Swiss court order freezing the bank accounts of General Sani Abacha's family is but one indication of the scope for legal, ethical, and political challenges to the ownership of these assets. Not only did capital flight itself generally violate foreign-exchange controls 
(hence its omission from the official balance of payments), but in many cases the capital itself was acquired by legally dubious means.

Efforts to recover and repatriate illicit private fortunes are one way in which African peoples and their governments can attempt to repair the disjuncture between public external debts and private external assets. This is a difficult route, however, since it places the burden of proof squarely on the African governments to locate and reclaim the money (see, for example, The Financial Times, 1999). As a result, such efforts offer only limited possibilities for easing sub-Saharan Africa's public external debt burden.

An alternative, complementary strategy would apply the same principles to the region's external liabilities. Sub-Saharan African governments could inform their creditors that outstanding debts will be treated as legitimate if, and only if, the real counterparts of the borrowing can be identified. If the creditors can document where the money went, and show when and how it benefited citizens of the borrowing country via investment or consumption, then the debt will be regarded as a bona fide external obligation of the government (and hence an external asset of the creditor bank or government). But if the fate of the borrowed money cannot be traced, then the present African governments must infer that it was diverted into private pockets, and possibly into capital flight. In such cases, it can be argued, the liability for the debt lies not with the government, but with the private individuals whose personal fortunes are the real counterpart of the debts. 
In adopting such a strategy, Africans could invoke as a precedent the US government's stance toward the creditors of the erstwhile Spanish colonial regime in Cuba after the Spanish-American war, a century ago: the creditors knew, or should have known, the risks they faced when they made the loans to the predecessor regime, and they 'took the chances of the investment.

In effect, this strategy would accord equal treatment to Africa's external assets and liabilities. On both sides of the balance sheet, the burden of proof in realizing the face value of external claims would lie with the creditors: African governments seeking to reclaim flight capital, and banks and creditor governments seeking to collect debtservice payments. The case for symmetry is reinforced by the past complicity of subSaharan Africa's external creditors in sustaining the power of corrupt rulers and in helping them to spirit their ill-gotten gains abroad. As The Financial Times (2000) remarks, in an editorial comment on the freezing of General Abacha's Swiss bank accounts, 'Financial institutions that knowingly channeled the funds have much to answer for, acting not so much as bankers but as bagmen, complicit in the corruption that has crippled Nigeria.' The evidence presented here indicates that capital flight from Nigeria was simply an egregious example of a more widespread phenomenon in the subcontinent.

In recent years there has been much debate about 'debt forgiveness.' Proponents argue that, in view of the dire economic circumstances in the low-income countries of 
sub-Saharan Africa, their external debts should be written off. Opponents counter that debt relief would create a moral hazard, by encouraging undisciplined borrowing in the expectation that defaults will not be penalized, and that this in turn would make creditors reluctant to lend in the future. 'If you have a society based on debt forgiveness,' World Bank president James Wolfensohn told reporters at a February 2000 news conference, ‘who's going to invest in debt anymore? So you really screw up the market' (United Press International, 2000).

Yet moral hazard - the principle that when insured against a risk, people have less incentive to take precautions against it - cuts both ways in international financial markets. If external creditors are not held accountable for the economic results when their money props up venal rulers, then they too will feel little pressure to lend more responsibly in the future. If creditors enjoy impunity when they look the other way as these rulers transform public resources into private external assets, and in some cases even abet them in doing so, there is little reason to expect them to act differently in the years ahead. When the stock of capital flight from sub-Saharan Africa exceeds the subcontinent's external debt, and when the asymmetrical treatment of external liabilities and assets shelters the gains of a wealthy élite, while burdening millions of the world's poorest people with responsibility for repaying debts from which they derived little if any benefit, the market is already, in Mr Wolfensohn's blunt phrase, 'screwed up.' As the people of sub-Saharan Africa confront the twin financial legacies of debt and capital flight, they may well ask: Who should forgive whom? 


\section{Acknowledgements}

We are grateful to an anonymous referee for very helpful comments on an earlier version of this paper.

\section{NOTES}

${ }^{1}$ World Bank, World Development Indicators 1998, CD-ROM version. 'Low-income countries' were defined as countries with 1996 per capita incomes of $\$ 785$ or less; countries were defined as 'severely indebted' when their ratios of debt service to GNP, debt service to exports, debt to GNP, debt to exports, and/or interest to exports exceeded critical levels. Similarly, sub-Saharan Africa accounts for 33 of the 41 countries classified as 'heavily indebted poor countries' (HIPCs) under the joint World Bank-IMF initiative of that name (Boote and Thugge, 1999).

${ }^{2}$ We thus exclude middle-income countries such as South Africa, and less indebted lowincome countries such as Lesotho and Eritrea.

${ }^{3}$ In 1996, total debt service from the 25 countries in our sample amounted to $\$ 9.6$ billion; their combined GDP was $\$ 140$ billion (authors' computations using data from World Development Indicators 2000 and Global Development Finance 2000).

${ }^{4}$ For discussions of alternative methods used to compute capital flight, see Lessard and Williamson (1987), Boyce (1992), and Ajayi (1997)

${ }^{5}$ Hence the amount of capital flight is computed as:

$K F_{i t}=\Delta D E B T_{i t}+D F I_{i t}-\left(C A_{i t}+\Delta R E S_{i t}\right)-\Delta B_{i t}$ where $\Delta B$ is the change in the claims of domestic banks on foreign banks.

${ }^{6}$ Ajayi (1995) compared estimates of Nigerian capital flight using various methodologies for the same time period (1972-1989), and found that total capital flight is high regardless of the method used.

${ }^{7}$ For early discussions of trade misinvoicing, see Bhagwati (1964) and Gulati (1987).

${ }^{8}$ Even if the net effect of trade misinvoicing on capital flight estimates were zero, this would not necessarily imply that misinvoicing was unimportant as a mechanism of capital flight. It simply would mean that capital flight via export underinvoicing and import overinvoicing was offset by capital outflows to finance the undeclared portion of imports. Foreign exchange to finance the latter could have been moved abroad by other 
mechanisms, such as cash transfers and wire transfers (see Boyce, 1993, pp. 282-285, 294).

${ }^{9}$ Pastor (1990) produced estimates of capital flight including interest earnings for a sample of Latin American countries.

${ }^{10}$ Kenya is classified as a 'moderately indebted' low-income country in the World Bank's 1998 and 1999 World Development Indicators, but as severely indebted in previous editions. The country was also included in Ajayi's (1997) earlier study of the sub-Saharan SILICs. We therefore retained it in our sample as well.

11 These are 1996 figures, computed from data in World Development Indicators 2000.

12 Data on the change in external debt outstanding ( $\triangle D E B T$ ) were taken from the World Bank's Global Development Finance 2000; data on all other variables in the equation are from the IMF's Balance-of-Payments Statistics.

${ }^{13}$ On average, short-term debt accounts for roughly $14 \%$ of total debts for the 25 countries in our sample in the 1970-96 period. Data on its currency composition are not available.

${ }^{14}$ The series for the c.i.f./f.o.b. factor reported in the IMF's Direction of Trade Statistics Yearbooks are in some cases anomalous both in terms of absolute values and year-to-year variations. For example, the reported c.i.f./f.o.b. factor for Congo-Zaïre is higher than that of land-locked Burundi. Hence we use the average factor for each year for Africa as a whole in our computations.

${ }^{15}$ In general, we would not expect to find a negative sign on DXIC in the absence of incentives for overinvoicing of exports (such as export incentive programs). For discussion, see Gulati (1987).

${ }^{16}$ In some cases, the data reported in the IMF Direction of Trade Statistics Yearbooks show occasional wide, unexplained fluctuations in the shares of industrialized countries in some African countries' exports and imports. In our calculations, we use the average shares for each country over the 1970-1996 period.

${ }^{17}$ More precisely, TBILL is the annual average of the discount on new issues of threemonth Treasury bills, reported in the IMF's International Financial Statistics Yearbook.

${ }^{18}$ Some discrepancies with past estimates are to be expected, due to our adjustment for the effects of exchange rate fluctuations on debt stocks and to other methodological variations (e.g., some authors exclude banking-sector external assets, as noted above). In addition, we use more recent editions of the Balance of Payments of Payments Statistics Yearbook and the Global Development Finance 2000, which incorporate corrections to earlier data. 
19 The negative capital flight reported here for Mali and Niger in the period as a whole is anomalous, suggesting the need for further investigation.

${ }^{20}$ Here, as throughout this study, the years covered correspond to those reported in Table 2. Hence our data for Angola, Mozambique, and Zambia refer to the periods 1985-1996, 1982-1996, and 1970-1991, respectively.

21 The average annual ratio of capital flight to GDP, shown in column 1, provides a better indicator of relative burdens for those countries for which we do not have a complete 27-year time series.

22 According to Lessard and Williamson (1987, p. 83), foreign depositors at Swiss banks at times have accepted 'negative interest returns, implying that they were willing to pay a substantial premium for confidentiality.' See also Walter (1987).

23 Official creditors have already written off substantial amounts of African debt. In June 1999, for example, President Jacques Chirac announced that France would cancel \$6 billion worth of debt owed by Africa's poorest nations (Deutsche Presse-Agentur, 1999). Commercial banks have sold African debt on the secondary market at a fraction of its face value; in 1994, for example, Sudan's debt traded for as little as six cents on the dollar (Corrigan, 1994). In 1999, the debts of 20 African countries reportedly traded at less than $20 \%$ of face value (Garrett and Travis 1999, p. 33).

${ }^{24}$ For a taxonomy of linkages between debt and capital flight, see Boyce (1992, 1993).

25 For discussion, see Hoeflich (1982) and Ndikumana and Boyce (1998). 


\section{References}

Ajayi, Ibi S. (1992) 'An Economic Analysis of Capital Flight from Nigeria,' World Bank, Working Paper 993.

Ajayi, Ibi S. (1995) 'Capital Flight and External Debt in Nigeria,' African Economic Research Consortium, Research Paper 35.

Ajayi, Ibi S. (1997) 'An Analysis of External Debt and Capital Flight in the Severely Indebted Low Income Countries in Sub-Saharan Africa,' IMF, Working Paper WP/97/68.

Bhagwati, Jagdish N. (1964) 'On the Underinvoicing of Imports,' Bulletin of the Oxford University Institute of Statistics, November.

Boote, Anthony R. and Kamau Thugge (1999) Debt Relief for Low-Income Countries: The HIPC Initiative. Washington, D.C.: International Monetary Fund.

Boyce, James K. (1992) 'The Revolving Door? External Debt and Capital Flight: A Philippine Case Study,' World Development, 20(3): 335-349.

Boyce, James K. (1993) The Philippines. The Political Economy of Growth and Impoverishment in the Marcos Era. London: MacMillan.

Burns, Jimmy, Michael Holman, and Mark Huband (1997) 'How Mobutu Build Up His $\$ 4$ bn Fortune: Zaire's Dictator Plundered IMF Loans,' Financial Times, 12 May, p. 1.

Chang, Kevin P.H. and Robert E. Cumby (1991) 'Capital Flight in Sub-Saharan African Countries,' in Ishrat Husain and John Underwood, eds., African External Finance in the 1990s. Washington, DC.: World Bank, 162-187.

Claessens, Stijn and David Naudé (1993) 'Recent Estimates of Capital Flight,' World Bank, Working Paper 1186.

Corrigan, Tracy (1994) 'Picking Up the Pieces of an Emerging market,' Financial Times, 5 April, p. 17.

Deutsche Presse-Agentur (1999) 'France Canceling Poorest Africans' Debt,' wire service report, dateline Cologne, 18 June (available on Lexis-Nexis).

Erbe, Suzanne (1985) 'The Flight of Capital From Developing Countries,' Intereconomics, (November/December), 268-275.

Financial Times (1999) 'Nigeria Seeks Help in Tracing Billions 'Taken' by Former Military Leaders', 23 July, p. 5. 
Financial Times (2000) ‘Abacha’s Loot,' lead editorial, 28 January.

Garrett, John and Angela Travis (1999) Unfinished Business: The World's Leaders and the Millennium Debt Challenge. London: Jubilee 2000 Coalition.

Gerth, Jeff (1999) 'Hearings Offer View Into Private Banking,' New York Times, 8 November, p. A6.

Gulati, Sunil K. (1987) 'A Note on Trade Misinvoicing,' in Lessard, Donald R. and John Williamson, eds., Capital Flight and Third World Debt. Washington, D.C.: Institute for International Economics, 68-78.

Hermes, Niels and Robert Lensink (1992) 'The Magnitude and Determinants of Capital Flight: The Case for Six Sub-Saharan African Countries,' De Economist 140(4), 515-530.

Hoeflich, M.E. (1982) 'Through a Glass Darkly: Reflections Upon the History of the International Law of Public Debt in Connection with State Succession,' University of Illinois Law Review 1: 39-70.

IMF, Balance of Payments Statistics Yearbook (various issues)

IMF, Direction of Trade Statistics Yearbook (various issues)

IMF, International Financial Statistics Yearbook (various issues).

International Finance Corporation (1998) 'Trends in Private Investment in Developing Countries, Statistics for 1970-96,' Discussion paper 34.

Lensink, Robert, Niels Hermes and Victor Murinde (1998) 'The Effect of Financial Liberalization on Capital Flight in African Economies,' World Development 26(7): 1349-1368.

Lessard, Donald R. and John Williamson eds. (1987) Capital Flight and Third World Debt. Washington, D.C.: Institute for International Economics.

Morgan Guaranty Trust Company (1986) 'LDC Capital Flight,' World Financial Markets (March), 13-15.

Murinde, Victor, Niels Hermes, and Robert Lensink (1996) 'Comparative Aspects of the Magnitude and Determinants of Capital Flight in Six Sub-Saharan African Countries,' Saving and Development XX(1), 61-78.

Ndikumana, Léonce (2000) 'Financial Determinants of Domestic Investment in SubSaharan Africa: Evidence from Panel Data,' World Development 28(2), 381-400. 
Ndikumana, Léonce and James K. Boyce (1998) 'Congo’s Odious Debt: External Borrowing and Capital Flight in Zaire,' Development and Change, 29, 195-217.

Nyatepe-Coo, Akorlie A. (1994) 'Capital Flight in Low-Income Sub-Saharan Africa: The Effects of Political Climate and Macroeconomic Policies,' Scandinavian Journal of Development Alternatives, (December), 59-68.

O’Brien, Timothy L. (1999) 'Panel to Focus on U.S. Bank and Deposits by Africans,' New York Times, 5 November, p. A11.

Ojo, Oladeji O. (1992) 'An Empirical Investigation of Capital Flight in Selected African Countries,' Abidjan: African Development Bank, Economic Research Papers No. 17.

Onishi, Norimitsu (1999) 'Going After 'Big Fish,' New Nigerian President Trawls for Corruption,' International Herald Tribune, 25 November 1999, p. 2.

Pastor, Manuel (1990) 'Capital Flight From Latin America,' World Development, 18(1): $1-18$.

Smit, B. W. and B. A. Mocke (1991) 'Capital Flight From South Africa: Magnitudes and Causes,' South African Journal of Economics, 59(2), 101-117.

United Press International (2000) 'Wolfensohn: Wider debt relief to poor nations impractical,' wire service report, dateline Manila, 26 February (available on Lexis-Nexis).

Walter, Ingo (1987) 'The Mechanisms of Capital Flight,' in Donald R. Lessard and John Williamson, eds., Capital Flight and Third World Debt. Washington, D.C.: Institute for International Economics, pp. 103-128.

World Bank (1985) World Development Report 1985. Washington, D.C.: World Bank.

World Bank (1998) World Development Indicators 1998 (CD-ROM edition).

World Bank (2000) World Development Indicators 2000 (CD-ROM edition).

World Bank (2000) Global Development Finance 2000 (CD-ROM edition). 
Table 1: Currency composition of long-term debt: weighted averages ${ }^{\mathrm{a}}$ 1970-1996

\begin{tabular}{|c|c|c|c|c|c|c|c|c|c|}
\hline Country & UK Pound & $\begin{array}{l}\text { French } \\
\text { franc }\end{array}$ & $\begin{array}{l}\text { Deutsche } \\
\text { mark }\end{array}$ & $\begin{array}{l}\text { Japanese } \\
\text { yen }\end{array}$ & $\begin{array}{l}\text { Swiss } \\
\text { franc }\end{array}$ & US dollar & SDR & $\begin{array}{l}\text { Multiple } \\
\text { currencies }\end{array}$ & $\begin{array}{l}\text { Other } \\
\text { currencies }\end{array}$ \\
\hline Angola & 1.0 & 3.7 & 0.2 & 0.3 & 0.3 & 81.7 & 0.2 & 0.8 & 11.8 \\
\hline Burkina Faso & 0.6 & 20.2 & 1.5 & 0.0 & 0.0 & 41.3 & 1.6 & 14.4 & 20.3 \\
\hline Burundi & 0.0 & 8.6 & 0.5 & 1.8 & 0.2 & 47.6 & 2.1 & 21.3 & 17.9 \\
\hline Cameroon & 1.8 & 31.5 & 14.0 & 0.2 & 0.8 & 14.3 & 0.1 & 15.2 & 22.1 \\
\hline Central African Republic & 0.2 & 18.0 & 1.5 & 0.4 & 2.9 & 42.5 & 5.6 & 16.2 & 12.7 \\
\hline Congo, DRC & 1.8 & 14.8 & 6.9 & 3.0 & 0.2 & 43.6 & 0.2 & 2.8 & 26.7 \\
\hline Congo, Rep. & 4.8 & 43.6 & 2.4 & 0.2 & 0.6 & 21.6 & 0.6 & 3.5 & 22.9 \\
\hline Côte d'Ivoire & 1.0 & 35.5 & 4.1 & 0.8 & 2.6 & 23.6 & 0.5 & 19.5 & 12.5 \\
\hline Ethiopia & 0.4 & 0.1 & 2.2 & 0.6 & 0.1 & 27.0 & 0.2 & 5.9 & 63.5 \\
\hline Ghana & 6.7 & 2.4 & 7.7 & 6.8 & 0.2 & 50.9 & 0.5 & 7.9 & 16.9 \\
\hline Guinea & 2.0 & 10.9 & 2.3 & 1.7 & 0.5 & 35.3 & 0.5 & 7.1 & 39.6 \\
\hline Kenya & 9.9 & 5.9 & 5.3 & 9.6 & 3.6 & 31.6 & 0.2 & 20.7 & 13.2 \\
\hline Madagascar & 0.1 & 22.2 & 4.0 & 6.7 & 1.1 & 42.2 & 2.4 & 6.9 & 14.4 \\
\hline Malawi & 16.5 & 1.8 & 1.5 & 8.0 & 0.1 & 44.6 & 2.3 & 19.0 & 6.3 \\
\hline Mali & 5.0 & 28.4 & 1.2 & 0.9 & 2.9 & 16.9 & 0.0 & 12.5 & 32.1 \\
\hline Mauritania & 0.5 & 7.7 & 1.7 & 1.6 & 0.0 & 36.5 & 1.8 & 4.0 & 46.2 \\
\hline Mozambique & 2.1 & 10.1 & 4.6 & 1.9 & 0.0 & 60.0 & 1.2 & 5.9 & 14.3 \\
\hline Niger & 1.0 & 48.2 & 0.9 & 1.6 & 0.2 & 26.5 & 1.7 & 0.7 & 19.3 \\
\hline Nigeria & 10.1 & 8.1 & 13.8 & 8.8 & 0.9 & 38.6 & 0.0 & 12.6 & 7.0 \\
\hline Rwanda & 0.0 & 7.0 & 0.7 & 1.8 & 0.0 & 42.8 & 4.4 & 12.2 & 31.0 \\
\hline Sierra Leone & 4.2 & 4.5 & 6.7 & 6.3 & 6.8 & 33.4 & 7.7 & 6.7 & 23.8 \\
\hline Sudan & 4.6 & 2.9 & 1.1 & 2.3 & 13.4 & 51.0 & 0.4 & 1.9 & 22.3 \\
\hline Tanzania & 8.8 & 2.6 & 2.8 & 25.6 & 0.3 & 27.3 & 1.9 & 5.9 & 24.8 \\
\hline Uganda & 8.3 & 2.5 & 1.3 & 0.9 & 1.3 & 54.6 & 3.2 & 17.2 & 10.8 \\
\hline Zambia & 7.8 & 2.7 & 9.8 & 8.3 & 0.3 & 33.1 & 0.3 & 14.3 & 23.4 \\
\hline Total & 5.0 & 13.1 & 6.2 & 5.3 & 2.0 & 37.7 & 0.6 & 10.0 & 20.1 \\
\hline
\end{tabular}

Source: Authors' computations from Global Development Finance 2000 (CDROM edition).

${ }^{a}$ Averages for the 27-year period weighted by total long-term debt. 
Table 2: Estimates of total real capital flight without adjustment for trade misinvoicing (million 1996 US \$)

\begin{tabular}{|l|r|r|c|}
\hline Country & Total capital flight & Annual average & Period \\
\hline Angola & 18237.0 & 1519.7 & $1985-1996$ \\
Burkina Faso & 35.1 & 1.4 & $1970-1994$ \\
Burundi & 43.0 & 3.6 & $1985-1996$ \\
Cameroon & 5335.4 & 197.6 & $1970-1996$ \\
Central African Republic & 86.1 & 3.4 & $1970-1994$ \\
Congo (DRC - Zaïre) & 5990.5 & 221.9 & $1970-1996$ \\
Congo (Rep.) & -466.1 & -17.9 & $1971-1996$ \\
Côte d'Ivoire & 16639.2 & 616.3 & $1970-1996$ \\
Ethiopia & 10143.4 & 375.7 & $1970-1996$ \\
Ghana & 3433.5 & 127.2 & $1970-1996$ \\
Guinea & 602.3 & 54.8 & $1986-1996$ \\
Kenya & 400.4 & 14.8 & $1970-1996$ \\
Madagascar & 1670.9 & 61.9 & $1970-1996$ \\
Malawi & -1170.5 & -46.8 & $1970-1994$ \\
Mali & -772.3 & -28.6 & $1970-1996$ \\
Mauritania & 631.9 & 27.5 & $1973-1995$ \\
Mozambique & 5526.7 & 368.4 & $1982-1996$ \\
Niger & -978.6 & -37.6 & $1970-1995$ \\
Nigeria & 63181.5 & 2340.1 & $1970-1996$ \\
Rwanda & -12.1 & -0.4 & $1970-1996$ \\
Sierra Leone & -248.9 & -9.6 & $1970-1995$ \\
Sudan & 13854.4 & 513.1 & $1970-1996$ \\
Tanzania & 1693.0 & 62.7 & $1970-1996$ \\
Uganda & 2889.5 & 107.0 & $1970-1996$ \\
Zambia & 5807.1 & 264.0 & $1970-1991$ \\
& & & \\
\hline Total & 152552.4 & 269.6 & \\
\hline
\end{tabular}

Sources: Authors' computations using data from:

- World Bank, Global Development Finance 2000 (CD-ROM edition);

- World Bank, World Development Indicators 2000 (CD-ROM edition);

- IMF, Balance of Payments Statistics Yearbook (various issues);

- IMF, International Financial Statistics Yearbook (various issues). 
Table 3: Total trade misinvoicing, 1970-1996 ${ }^{\mathrm{a}, \mathrm{b}}$ (million 1996 US \$)

\begin{tabular}{|l|r|r|r|r|}
\hline Country & \multicolumn{1}{|l|}{$\begin{array}{l}\text { Export } \\
\text { misinvoicing }\end{array}$} & $\begin{array}{l}\text { Import } \\
\text { misinvoicing }\end{array}$ & $\begin{array}{l}\text { Net } \\
\text { misinvoicing }\end{array}$ & $\begin{array}{r}\text { Annual } \\
\text { average }\end{array}$ \\
\hline Angola & -743.7 & -460.7 & -1204.5 & -100.4 \\
Burkina Faso & 869.0 & 361.4 & 1230.4 & 49.2 \\
Burundi & 797.0 & -21.1 & 775.9 & 64.7 \\
Cameroon & 10778.3 & -3014.3 & 7764.0 & 287.6 \\
Central African Republic & 353.6 & -189.5 & 164.1 & 6.6 \\
Congo (DRC-Zaïre) & 14478.1 & -7080.7 & 7397.4 & 274.0 \\
Congo (Rep.) & 3669.6 & -2744.3 & 925.3 & 35.6 \\
Côte d'Ivoire & 8884.3 & -2152.5 & 6731.8 & 249.3 \\
Ethiopia & 757.8 & -5378.4 & -4620.6 & -171.1 \\
Ghana & -218.3 & -2807.8 & -3026.1 & -112.1 \\
Guinea & -127.5 & -132.1 & -259.5 & -23.6 \\
Kenya & 6207.2 & -5792.5 & 414.7 & 15.4 \\
Madagascar & 1522.9 & -1544.9 & -22.0 & -0.8 \\
Malawi & -259.2 & 2134.7 & 1875.6 & 75.0 \\
Mali & -96.2 & -335.1 & -431.3 & -16.0 \\
Mauritania & 1265.6 & -766.7 & 498.9 & 21.7 \\
Mozambique & 1.2 & -216.6 & -215.4 & -14.4 \\
Niger & -632.3 & -1542.1 & -2174.5 & -83.6 \\
Nigeria & 16255.8 & 7324.6 & 23580.4 & 873.3 \\
Rwanda & 657.1 & 1470.9 & 2128.0 & 78.8 \\
Sierra Leone & 2725.2 & -1003.6 & 1721.6 & 66.2 \\
Sudan & 2323.8 & -9195.5 & -6871.7 & -254.5 \\
Tanzania & 1810.0 & -1803.9 & 6.1 & 0.2 \\
Uganda & -976.5 & 241.9 & -734.6 & -27.2 \\
Zambia & 1123.9 & 3692.4 & 4816.3 & 218.9 \\
& & & & \\
\hline Total & 71426.7 & -30956.4 & 40470.3 & 60.5 \\
\hline
\end{tabular}

Sources: Authors' computations using data from:

- IMF, Direction of Trade Statistics Yearbook (various issues);

- IMF, International Financial Statistics Yearbook (various issues).

Notes:

${ }^{\mathrm{a}}$ Data refer to the same time periods indicated in Table 2.

${ }^{\mathrm{b}}$ A positive sign for misinvoicing represents a net addition to capital flight (see text). 
Table 4: Total real capital flight adjusted for trade misinvoicing ${ }^{\text {a }}$ (million 1996 US \$)

\begin{tabular}{|c|c|c|}
\hline Country & Real capital flight $^{b}$ & $\begin{array}{l}\text { With imputed } \\
\text { interest earnings }\end{array}$ \\
\hline Angola & 17032.5 & 20405.0 \\
\hline Burkina Faso & 1265.5 & 1896.6 \\
\hline Burundi & 818.9 & 980.9 \\
\hline Cameroon & 13099.4 & 16906.0 \\
\hline Central African Republic & 250.2 & 459.0 \\
\hline Congo (DRC - Zaïre) & 13387.8 & 22990.5 \\
\hline Congo (Rep.) & 459.2 & 1254.0 \\
\hline Côte d'Ivoire & 23371.0 & 34745.5 \\
\hline Ethiopia & 5522.8 & 8017.9 \\
\hline Ghana & 407.3 & 289.3 \\
\hline Guinea & 342.8 & 434.2 \\
\hline Kenya & 815.1 & 2472.6 \\
\hline Madagascar & 1649.0 & 1577.5 \\
\hline Malawi & 705.1 & 1174.8 \\
\hline Mali & -1203.6 & -1527.2 \\
\hline Mauritania & 1130.8 & 1830.0 \\
\hline Mozambique & 5311.3 & 6206.9 \\
\hline Niger & -3153.1 & -4768.9 \\
\hline Nigeria & 86761.9 & 129661.0 \\
\hline Rwanda & 2115.9 & 3513.9 \\
\hline Sierra Leone & 1472.8 & 2277.8 \\
\hline Sudan & 6982.7 & 11613.7 \\
\hline Tanzania & 1699.1 & 6203.4 \\
\hline Uganda & 2154.9 & 3316.1 \\
\hline Zambia & 10623.5 & 13131.2 \\
\hline Total & 193022.8 & 285061.7 \\
\hline
\end{tabular}

Sources: Authors' computations using data from:

- IMF, Direction of Trade Statistics Yearbook (various issues);

- IMF, International Financial Statistics Yearbook (various issues);

- World Bank, World Development Indicators 2000, (CD-ROM edition);

- World Bank, Global Development Finance 2000 (CD-ROM edition).

Notes:

${ }^{\mathrm{a}}$ Data refer to the same time periods indicated in Table 2.

${ }^{\mathrm{b}}$ Converted to 1996 US dollars using the United States producer price index (PPI).

${ }^{\mathrm{c}}$ Includes imputed interest earnings at the United States Treasury Bill rate. 
Table 5: Per capita capital flight relative to GDP

\begin{tabular}{|c|c|c|c|c|}
\hline \multirow[t]{2}{*}{ Country } & \multirow{2}{*}{$\begin{array}{l}\text { Average } \\
\text { annual capital } \\
\text { flight } \\
\text { (\% of GDP) }\end{array}$} & \multicolumn{2}{|c|}{$\begin{array}{l}\text { Accumulated capital flight }{ }^{\mathrm{a}, \mathrm{b}} \\
\text { (with interest earnings) }\end{array}$} & \multirow{2}{*}{$\begin{array}{l}\text { GDP per } \\
\text { capita } \\
1996^{b}\end{array}$} \\
\hline & & $\%$ of 1996 GDP & Per capita $(\$)$ & \\
\hline Angola & 19.2 & 267.8 & 1803 & 673 \\
\hline Burkina Faso & 2.5 & 96.5 & 194 & 201 \\
\hline Burundi & 5.6 & 108.9 & 156 & 143 \\
\hline Cameroon & 3.9 & 185.6 & 1248 & 672 \\
\hline Central African & 1.4 & 50.8 & 143 & 281 \\
\hline Republic & & & & \\
\hline Congo (DRC - Zaïre) & 3.2 & 391.7 & 508 & 130 \\
\hline Congo (Rep.) & -1.0 & 49.6 & 476 & 959 \\
\hline Côte d'Ivoire & 7.9 & 324.7 & 2502 & 770 \\
\hline Ethiopia & 5.9 & 133.4 & 138 & 103 \\
\hline Ghana & 0.4 & 4.2 & 17 & 395 \\
\hline Guinea & 1.1 & 11.0 & 64 & 586 \\
\hline Kenya & 0.5 & 26.8 & 89 & 330 \\
\hline Madagascar & 2.0 & 39.5 & 115 & 291 \\
\hline Malawi & 2.4 & 93.8 & 124 & 132 \\
\hline Mali & -2.0 & -57.5 & -153 & 266 \\
\hline Mauritania & 4.7 & 167.4 & 786 & 469 \\
\hline Mozambique & 12.2 & 218.4 & 382 & 175 \\
\hline Niger & -4.9 & -247.7 & -521 & 210 \\
\hline Nigeria & 8.4 & 367.3 & 1132 & 308 \\
\hline Rwanda & 4.3 & 249.9 & 522 & 209 \\
\hline Sierra Leone & 4.7 & 257.1 & 505 & 196 \\
\hline Sudan & 1.6 & 161.1 & 428 & 265 \\
\hline Tanzania & -2.5 & 106.3 & 203 & 191 \\
\hline Uganda & 3.1 & 54.8 & 168 & 306 \\
\hline Zambia & 12.0 & 354.9 & 1637 & 461 \\
\hline Total & 3.8 & 203.8 & 583 & 286 \\
\hline
\end{tabular}

Sources: Authors' computations using data from:

- IMF, Direction of Trade Statistics Yearbook (various issues);

- IMF, International Financial Statistics Yearbook (various issues);

- World Bank, World Development Indicators 2000 (CD-ROM edition);

- World Bank, Global Development Finance 2000 (CD-ROM edition).

Notes: ${ }^{a}$ Cumulative capital flight includes imputed interest earning at the United States Treasury Bill rate.

${ }^{\mathrm{b}}$ The values for cumulative capital flight and real GDP are for 1996 except for some countries whose capital flight series end before 1996. The relevant years for these countries are: 1994 for Burkina Faso, Central African Republic, and Malawi; 1995 for Mauritania, Niger, and Sierra Leone; and 1991 for Zambia. 


\section{Table 6: External debt and net external assets (million 1996 US \$)}

\begin{tabular}{|c|c|c|c|}
\hline \multirow[t]{2}{*}{ Country } & \multirow{2}{*}{$\begin{array}{l}\text { Debt stock } \\
\text { (1996) }\end{array}$} & \multicolumn{2}{|c|}{ Net external assets } \\
\hline & & $\begin{array}{l}\text { Real capital flight } \\
\text { minus debt stock }\end{array}$ & $\begin{array}{l}\text { Cumulative capital } \\
\text { flight (with interest) } \\
\text { minus debt stock }\end{array}$ \\
\hline Angola & 11225.1 & 5807.4 & 9179.9 \\
\hline Burkina Faso & 1196.1 & 69.4 & 700.4 \\
\hline Burundi & 1126.9 & -308.0 & -146.0 \\
\hline Cameroon & 9541.6 & 3557.8 & 7364.4 \\
\hline Central African & 941.1 & -691.0 & -482.1 \\
\hline Republic & & & \\
\hline Congo (DRC- Zaïre) & 12826.4 & 561.4 & 10164.1 \\
\hline Congo (Rep.) & 5240.6 & -4781.4 & -3986.6 \\
\hline Côte d'Ivoire & 19523.6 & 3847.4 & 15221.9 \\
\hline Ethiopia & 10078.6 & -4555.8 & -2060.7 \\
\hline Ghana & 6442.2 & -6034.9 & -6152.9 \\
\hline Guinea & 3240.3 & -2897.5 & -2806.1 \\
\hline Kenya & 6931.0 & -6115.9 & -4458.4 \\
\hline Madagascar & 4145.8 & -2496.8 & -2568.3 \\
\hline Malawi & 2146.1 & -1441.0 & -971.3 \\
\hline Mali & 3006.0 & -4209.6 & -4533.2 \\
\hline Mauritania & 2404.2 & -1273.4 & -572.2 \\
\hline Mozambique & 7566.3 & -2255.0 & -1359.4 \\
\hline Niger & 1623.3 & -4776.3 & -6392.1 \\
\hline Nigeria & 31406.6 & 55355.3 & 98254.4 \\
\hline Rwanda & 1043.1 & 1072.8 & 2470.8 \\
\hline Sierra Leone & 1205.1 & 267.6 & 1072.7 \\
\hline Sudan & 16972.0 & -9989.3 & -5358.3 \\
\hline Tanzania & 7361.8 & -5662.7 & -1158.4 \\
\hline Uganda & 3674.4 & -1519.5 & -358.3 \\
\hline Zambia & 7639.4 & 2984.1 & 5491.8 \\
\hline Total & 178507.6 & 14515.1 & 106556.1 \\
\hline
\end{tabular}

Sources: Authors' computations using data from:

- IMF, Direction of Trade Statistics Yearbook (various issues);

- IMF, International Financial Statistics Yearbook (various issues);

- World Bank, World Development Indicators 2000, (CD-ROM edition);

- World Bank, Global Development Finance 2000, (CD-ROM edition).

Notes:

The values for cumulative capital flight and debt stock are for 1996 except for some countries whose capital flight series end before 1996. The relevant years for these countries are: 1994 for Burkina Faso, Central African Republic, and Malawi; 1995 for Mauritania, Niger, and Sierra Leone; and 1991 for Zambia. 
Table A1: Real capital flight, 1970-1996 (adjusted for trade misinvoicing; million 1996 US \$)

\begin{tabular}{|c|c|c|c|c|c|c|c|c|c|c|c|}
\hline Year & 1970 & 1971 & 1972 & 1973 & 1974 & 1975 & 1976 & 1977 & 1978 & 1979 & 1980 \\
\hline Angola & $\mathrm{NA}$ & NA & NA & $\mathrm{NA}$ & NA & NA & NA & $\mathrm{NA}$ & $\mathrm{NA}$ & NA & $\mathrm{NA}$ \\
\hline Burkina Faso & 50.4 & 49.3 & 15.1 & 19.6 & 122.1 & -46.4 & -14.1 & 105.6 & 167.6 & 36.2 & 139.5 \\
\hline Burundi & NA & NA & NA & NA & NA & NA & NA & NA & NA & NA & NA \\
\hline Cameroon & -84.7 & -31.6 & -267.7 & -474.6 & -21.7 & 144.4 & -110 & 462.7 & 128.1 & -392.8 & 232.1 \\
\hline Central African & -15.3 & 17.4 & 21.4 & 76.2 & -4.5 & -7.2 & 31.5 & -25.7 & -25 & -11.1 & -10.1 \\
\hline Republic & & & & & & & & & & & \\
\hline Congo DRC & 801.6 & 263.8 & 849.9 & 1907.2 & 1534.9 & 99.8 & 465.3 & -1567.2 & 2002.9 & 771.9 & 916.1 \\
\hline Congo Rep. & NA & -51.4 & -11.5 & 116.9 & -231.5 & -494.3 & -853.3 & -60.5 & 253 & 234.4 & 439.6 \\
\hline Côte d'Ivoire & 267 & 306.2 & 388.2 & 481 & 244.4 & 853.5 & 576.5 & 1969.2 & 1404.6 & 260.5 & 1323.6 \\
\hline Ethiopia & 31.9 & -10.2 & -530.7 & 78.8 & -97.5 & -76.7 & -217.5 & -113.2 & 17.6 & -106.9 & -168.1 \\
\hline Ghana & -53.3 & -294.1 & 317.8 & 370.4 & -610.4 & 133.3 & -370.2 & 114.4 & -37.3 & 110.4 & 304.3 \\
\hline Guinea & NA & NA & NA & NA & NA & NA & NA & NA & NA & NA & NA \\
\hline Kenya & 36.4 & 90.4 & 84.1 & 412.1 & 526.6 & 449.4 & 345.8 & 84.6 & 190.8 & -38.4 & 77.9 \\
\hline Madagascar & 22.6 & 1381.2 & 270.4 & -82.7 & 655.4 & 180.7 & -1327.7 & 1424.4 & -1170 & -85.1 & -300.1 \\
\hline Malawi & 11.1 & 88.5 & -35.4 & 161.9 & 143.2 & 192.9 & 161.1 & 156.7 & 52.7 & -352.1 & -63 \\
\hline Mali & 58.2 & -88.9 & 51.2 & 80 & 50.4 & -62.2 & -131.6 & -35.2 & -2.2 & -230.8 & 58.5 \\
\hline Mauritania & NA & NA & NA & 304.1 & 408.6 & -214.8 & 230.6 & 57.4 & 75.5 & -106.7 & 4.1 \\
\hline Mozambique & NA & NA & NA & NA & NA & NA & NA & NA & NA & NA & NA \\
\hline Niger & 55.2 & 62.4 & 83.1 & 104.2 & -180.8 & -193.8 & -320.4 & -321.6 & 1 & -478.5 & 88.1 \\
\hline Nigeria & -485.1 & -564.2 & 626.1 & 3634.8 & 1448.2 & 1857.7 & 4162.4 & 9022.8 & 4060.4 & -612.9 & 2093.1 \\
\hline Rwanda & -106.1 & 30.7 & 24.7 & 34.4 & 34.9 & 67.7 & 77 & 119 & 288.7 & 320.9 & 223.8 \\
\hline Sierra Leone & 42.9 & 236 & 32.6 & 299 & 185.3 & -26.8 & 92.8 & 92.2 & 3.7 & 29.3 & 57.1 \\
\hline Sudan & 45.3 & 107.2 & -226.8 & 115.8 & 673.8 & 270.5 & 307.4 & 206.3 & -215.7 & 545.2 & 1004.1 \\
\hline Tanzania & 300.9 & 2985.2 & -104.8 & 790.6 & 822.7 & 582.9 & 450.2 & 402.6 & 387 & -367.3 & 402.4 \\
\hline Uganda & 213.2 & 67.9 & 6.2 & 136.7 & 64.1 & -23.3 & 51.8 & -306.3 & -90.7 & 325.2 & 70.4 \\
\hline Zambia & 1386.4 & 1328.7 & 104.4 & 260.7 & -393.4 & 104.3 & 84.3 & 605.2 & 455.5 & 944.3 & -274.6 \\
\hline
\end{tabular}


Table A1 (continued): Real capital flight, 1970-1996 (adjusted for trade misinvoicing; million 1996 US \$)

\begin{tabular}{|c|c|c|c|c|c|c|c|c|c|c|}
\hline Year & 1981 & 1982 & 1983 & 1984 & 1985 & 1986 & 1987 & 1988 & 1989 & 1990 \\
\hline Angola & NA & NA & NA & NA & 2452 & 724.2 & 2803.8 & 533.4 & 1144.7 & 731.9 \\
\hline Burkina Faso & 86.9 & 79.8 & 55.9 & 48.5 & -47 & 52.7 & 36.5 & -7.3 & 23.1 & 77.8 \\
\hline Burundi & NA & NA & NA & NA & 82.7 & 103.5 & 181.2 & 20.6 & 34.4 & -5.1 \\
\hline Cameroon & 222.6 & 329.6 & 629.2 & 1900 & -244 & 2166.4 & 1271.3 & 427.8 & 1371 & 1083.3 \\
\hline Central African Republic & 132.3 & 62.6 & 42.4 & 51.3 & 28.4 & 1.5 & 44.2 & 28.7 & -36 & -104.1 \\
\hline Congo DRC & 1715.9 & 530 & 289.2 & -79.8 & 778.2 & 366.4 & 514.7 & -585.6 & -292.2 & 1107.9 \\
\hline Congo Rep. & -240.5 & 623.2 & 392.2 & 690.4 & 688.5 & -326.8 & 886.8 & -390.2 & 215.6 & -177.8 \\
\hline Côte d'Ivoire & 289.6 & 969.5 & 183.3 & 212.7 & 701 & 1015.2 & 1718.5 & 1033.7 & 1375.9 & 2703.4 \\
\hline Ethiopia & 772.2 & 1649.2 & 618.8 & 185.6 & 707.6 & 421.3 & 1340 & -471.1 & -270.9 & 425.1 \\
\hline Ghana & -638.9 & 100.9 & 422.4 & 464 & -77 & -489.6 & 387.2 & -333.5 & 301.5 & 59.4 \\
\hline Guinea & NA & NA & NA & NA & NA & 120.1 & 217.9 & 48.4 & -328 & 171.9 \\
\hline Kenya & -331.4 & -123.7 & 241.3 & -431.3 & 625 & -259.4 & 567.4 & -310.3 & -333.8 & 316.7 \\
\hline Madagascar & -408.2 & -72 & -156.9 & 190.7 & -14.4 & 92.1 & 314.2 & -110 & -479.2 & -69.2 \\
\hline Malawi & -30.5 & -4.8 & 88.5 & -89.4 & 141.1 & 149.4 & 177 & 142.4 & 326 & 55.2 \\
\hline Mali & 70.4 & 30 & 83.7 & 201.3 & -145.6 & -282.6 & -121.5 & -310.3 & -169.7 & 65.9 \\
\hline Mauritania & -28.8 & 80.9 & 101.7 & 127.8 & 82.6 & -61.5 & 2.7 & -21.9 & -150.1 & 115.9 \\
\hline Mozambique & NA & -398.3 & -110.9 & 830.1 & 1373.8 & 121.8 & 84.3 & -299 & -223.5 & 175.7 \\
\hline Niger & -185 & -364.7 & 29.4 & 49 & 15 & -92.3 & -209.9 & -131.5 & -533.5 & 44.2 \\
\hline Nigeria & 9293.6 & -509.4 & 2836.1 & 341.2 & 2443.8 & 5835.9 & 5762.2 & 2164.5 & 2314.7 & 5105.5 \\
\hline Rwanda & -24.4 & 42.4 & 32.4 & 77 & 89.5 & 131.5 & 153.9 & 153.9 & 15.3 & 133.5 \\
\hline Sierra Leone & 72.3 & -158.8 & 78.6 & 31.6 & -34 & 56.2 & 91.7 & 21.8 & 20.2 & 13.6 \\
\hline Sudan & 303.7 & -182.8 & -97 & 1405.1 & 398.2 & -161.8 & 599.1 & 61.5 & 2192.5 & 845.8 \\
\hline Tanzania & 689.9 & 166 & 490.1 & 176 & 1416.6 & -6458.6 & -305.1 & 217.5 & -365.1 & -65.6 \\
\hline Uganda & 219 & 197.8 & 178.5 & 260.8 & 35 & 76.4 & 329.8 & -207.2 & -10.5 & 142.4 \\
\hline Zambia & 914.2 & -493.1 & 41.1 & 284.8 & 274.6 & 1099.4 & 830.1 & 825.9 & 1488.2 & 743.9 \\
\hline
\end{tabular}


Table A1 (end): Real capital flight, 1970-1996 (adjusted for trade misinvoicing; million 1996 US \$)

\begin{tabular}{|c|c|c|c|c|c|c|}
\hline Year & 1991 & 1992 & 1993 & 1994 & 1995 & 1996 \\
\hline Angola & 2002.7 & 1820.7 & 1438 & 1526.2 & 1566.9 & 288 \\
\hline Burkina Faso & -40.6 & 139.7 & 87.6 & 26.9 & NA & NA \\
\hline Burundi & 23.8 & 63.9 & 86.9 & 49.7 & 203.5 & -26.4 \\
\hline Cameroon & 815.1 & 1545.1 & 426.8 & 820.6 & 421.4 & 329.2 \\
\hline Central African Republic & 70.5 & -89 & -24.9 & -5.2 & NA & NA \\
\hline Congo DRC & 571.6 & 421.8 & 242.6 & 109.5 & 664.6 & -1013.3 \\
\hline Congo Rep. & -82.3 & 353.2 & 38.9 & -372.7 & 255.4 & -1435.9 \\
\hline Côte d'Ivoire & 1758.9 & 1314.3 & 1570.5 & -1574.5 & 1429.4 & 594.8 \\
\hline Ethiopia & 380.8 & 395.8 & 263.4 & 452.5 & 71.5 & -226.3 \\
\hline Ghana & -358.3 & 144.9 & -224.2 & 196.3 & 84.5 & 382.5 \\
\hline Guinea & 21 & -55.7 & 243.9 & 64.3 & -73.6 & -87.4 \\
\hline Kenya & -6.8 & -263.7 & -194.1 & -205.3 & -15.9 & -719.3 \\
\hline Madagascar & 416.8 & 298.3 & 103.6 & 286.1 & 451 & -163.1 \\
\hline Malawi & -181.8 & -180.6 & -109.5 & -295.6 & NA & NA \\
\hline Mali & -83.4 & 255.6 & -51.3 & -429.3 & 68.6 & -132.8 \\
\hline Mauritania & 14.4 & -249.5 & 169.5 & 61.6 & 126.4 & NA \\
\hline Mozambique & 191.5 & 709.9 & 336.2 & 2201.4 & 63 & 255.4 \\
\hline Niger & -370.3 & 57.2 & -70 & -170.6 & -118.9 & NA \\
\hline Nigeria & 8387.7 & 5688.6 & 4066.9 & 2851.8 & 1475.5 & 3459.9 \\
\hline Rwanda & 103.6 & 2.7 & -29.9 & -37.6 & 81.6 & 74.6 \\
\hline Sierra Leone & 215.6 & 310 & 102.6 & 31.8 & -424.5 & NA \\
\hline Sudan & -199.8 & 122.6 & 154.6 & 82.6 & -198.6 & -1176.1 \\
\hline Tanzania & -437.4 & -256.6 & -282.7 & 66.6 & 12 & -17.1 \\
\hline Uganda & 41 & 70.5 & 54 & 250.8 & 24.9 & -23.3 \\
\hline Zambia & 8.6 & NA & NA & NA & NA & NA \\
\hline
\end{tabular}
Sources: Authors' computations using data from: IMF, Direction of Trade Statistics Yearbook (various issues); IMF, International Financial Statistics Yearbook
(various issues); World Bank, World Development Indicators 2000 (CD-ROM edition); World Bank, Global Development Finance 2000 (CD-ROM edition). 
Figure 1: Accumulated capital flight (with interest earnings) and debt stock, 1996

(\% of GDP)

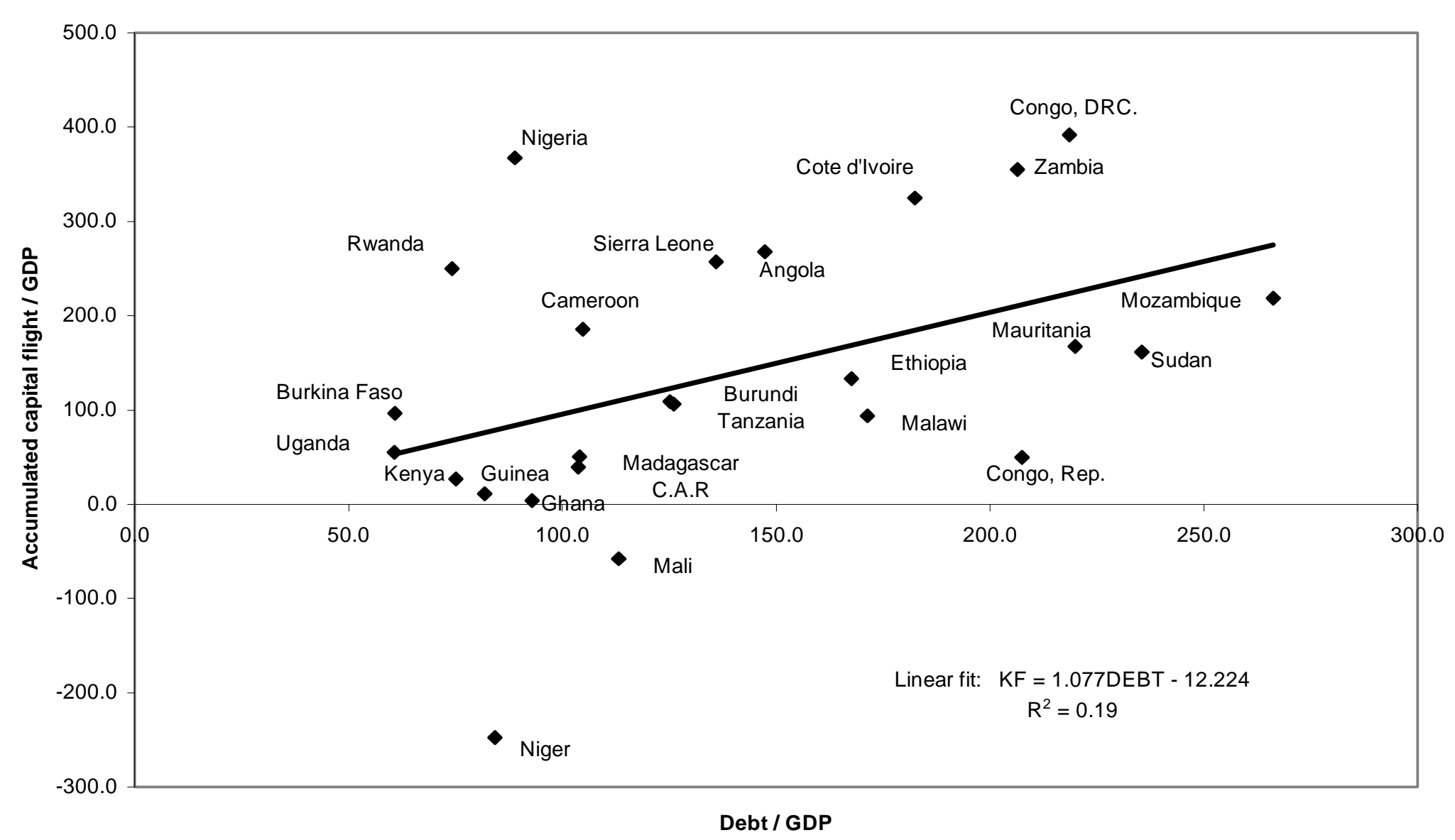


Figure 2: Real capital flight and debt flows for 25 sub-Saharan African countries, 1970-1996 (3-year moving averages ; million 1996 US \$)

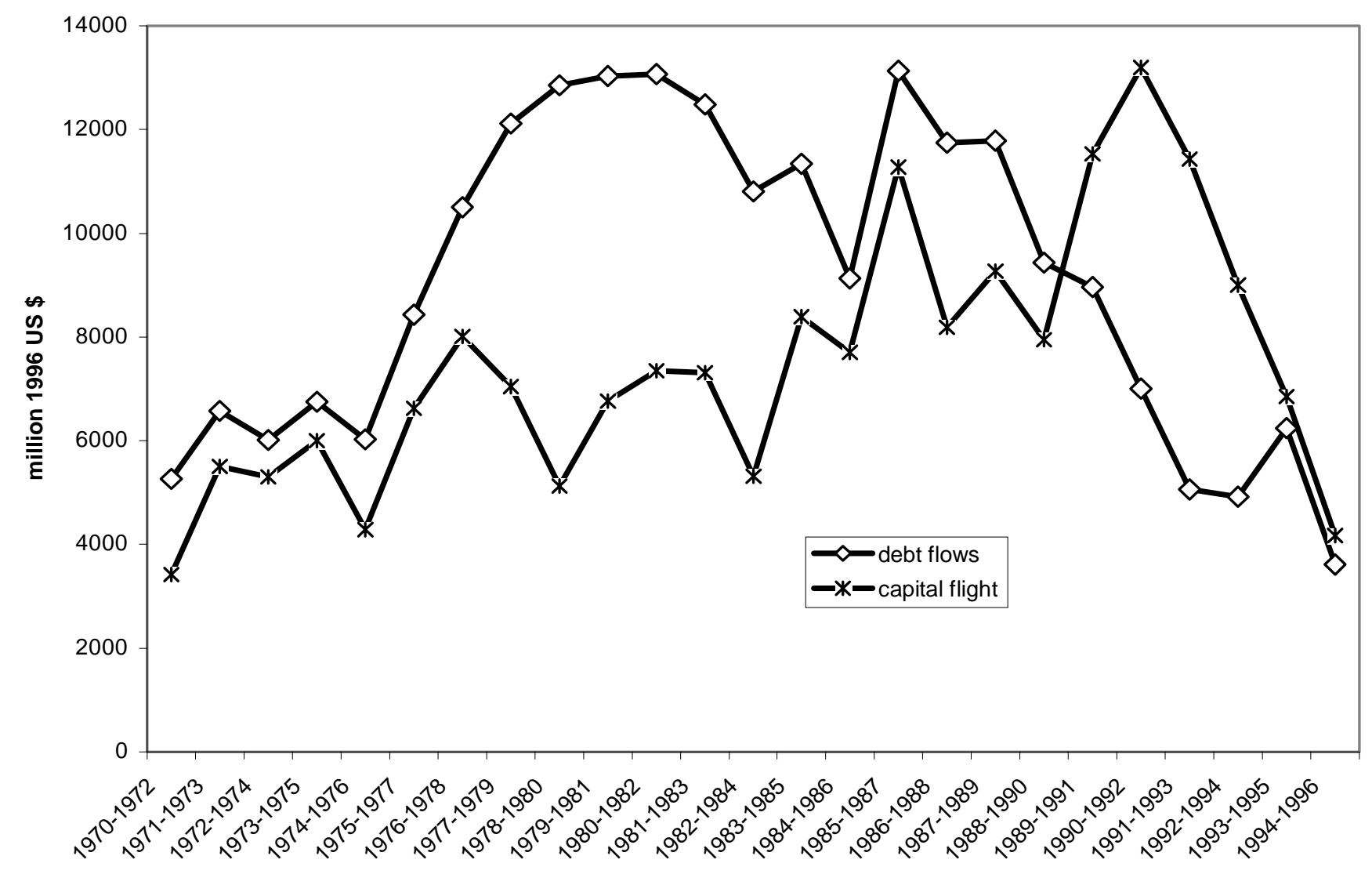

